\title{
Perception of Risk Behaviours Influencing HIV and AIDS Prevention and Control Among Secondary School Adolescents in Enugu State, Nigeria
}

\author{
Bernedeth N. Ezegbe ${ }^{1}$, Blessing Enyenwa ${ }^{2}$, Gloria Lebechi Ogbonna ${ }^{2}$, Chiedu Eseadi ${ }^{2}$, Chinyere Loveth Chukwu ${ }^{1}$, \\ Chukwudozie Joseph Emeka ${ }^{3} \&$ Luke Chizoba Ezema ${ }^{1}$ \\ ${ }^{1}$ Department of Social Science Education, University of Nigeria, Nsukka, Nigeria \\ ${ }^{2}$ Department of Educational Foundations, University of Nigeria, Nsukka, Nigeria \\ ${ }^{3}$ ONIT College of Education, Mbaukwu, Anambra State, Nigeria \\ Correspondence: Chinyere Loveth Chukwu, Department of Social Science Education, University of Nigeria, \\ Nsukka, P.M.B. 410001, Enugu State, Nigeria. E-mail: loveth.chukwu@unn.edu.ng
}

Received: February 28, 2019 Accepted: April 9, 2019 Online Published: April 14, 2019

doi:10.5539/gjhs.v11n6p10 URL: https://doi.org/10.5539/gjhs.v11n6p10

\begin{abstract}
Objective: The study investigated the secondary school adolescents' perception of risk behaviours influencing HIV and AIDS prevention and control in Enugu State, Nigeria.

Method: The study was a descriptive survey research. A sample of 825 senior secondary secondary school adolescents was selected. Three research questions and two hypotheses guided the study. Mean and Standard deviation was used to answer the research questions while t-test was used to test the hypotheses at 0.05 levels of significances.

Results: Results showed that there is a moderate level of HIV/AIDS risk perception among secondary school adolescents, a moderate level of HIV/AIDS risk perception among the male and female secondary school adolescents and also a moderate level of HIV/AIDS risk perception among the urban and rural secondary school adolescents. It further revealed that there is no significant difference between the mean rating of male and female secondary school adolescents in respect to their HIV/AIDS risk perception. It was also discovered from the study that there is significant difference between the mean rating of urban and rural secondary school adolescents with regards to their HIV/AIDS risk perception in favour of urban secondary school adolescents.
\end{abstract}

Conclusion: The study concludes that there is a moderate level of HIV/AIDS risk perception among secondary school adolescents in the study area. The level of HIV/AIDS risk perception among the male and female secondary school adolescents is moderate. There is a moderate level of HIV/AIDS risk perception among the urban and rural secondary school adolescents. Further studies could be carried out using a larger population to substantiate the urgency for counseling programme to meet the secondary school adolescents' needs on HIV/AIDS risk behaviours. Further research could also be focused on factors that affect adolescents' perception of risks which makes them vulnerable to HIV/AIDS.

Keywords: secondary school adolescents, risk behaviours, HIV/AIDS, risk perception

\section{Introduction}

Adolescence is a developmental period marked by discovery and experimentation following a myriad of physical and emotional changes. During this period, adolescents get mixed messages about different health issues. As a result, they can be vulnerable to contracting many infections like Human Immunodeficiency Virus/Acquired Immune Deficiency Syndrome (HIV/AIDS) (Smriti \& Marfatia, 2010). The origin of HIV/AIDS can be traced back to Kinshasa, in the Democratic Republic of Congo around 1920 when HIV crossed species from chimpanzees to humans (Avert, 2017). In 1981, AIDS epidemic was first recognized in United States among homosexual men. HIV, the virus that causes AIDS, was not isolated until 1983 (Remedy Health Media, 2017). In Nigeria, HIV/AIDS was identified in 1985 and was reported at an international AIDS conference in 1986 (Ssengonzi, Schlegel, Anyamele, \& Olson, 2004). Gender may influence the risk of HIV/AIDS infection. Girls account for three out of four new AIDS infections among adolescents aged 15 to 19 (UNICEF, 2018). Social norms about female sexuality 
make it very difficult for them to protect themselves from HIV infection as traditional norms of virginity for unmarried girls hinder adolescents freedom to seek important sexual health information, including knowledge about HIV risk, so in order to preserve their virginity, many adolescents engage in alternative sexual behaviours, such as anal sex, which can increase their risk of acquiring HIV (Gupta, 2000). The locality in which an individual finds himself may also influence his perception of HIV/AIDS risk behaviours. The study carried out by Vaghela (2015) reveals that the awareness to modes of transmission of HIV/AIDS in adolescent of urban area was $38 \%$ and adolescent of rural area was $24 \%$. It was also observed that adolescent of urban area have the misconception regarding the HIV/AIDS transmission is high in comparison to their rural counterparts.

There are several other factors that may account for new HIV/AIDS infections among adolescents. According to Adeyi, Kanki, Odutolu and Idoko (2006), about 80\% of HIV infections in Nigeria are due to heterosexual sex, lack of information about sexual health and HIV, and blood transfusions which account for up to $10 \%$ of new HIV infections. One of the factors also associated with HIV vulnerability among adolescents in Nigeria is early sexual debut, and very low HIV testing rates (Federal Ministry of Health, 2005). Federal Ministry of Health (2005) further stated that sexual debut among many adolescents in Nigeria usually begins at less than 15years of age. In Nigeria, socio-cultural norms also seem to be preventing secondary school adolescents from adopting preventive measures against HIV/AIDS infection. In addition, the risk of getting HIV appears to be dependent on an individual's behaviour (CDC, 2015).

Risk behaviours are lifestyle activities that place a person at increased risk of suffering a particular condition, illness or injury. Zwar, Mendelsohn, and Richmond, (2014) stated that risk behaviours are those behaviours that potentially expose people to harm or significant risk of harm. The risk behaviours of adolescents could be due to their perceptions. In the context of HIV, an individual perception of the risk of HIV infections often affects a number of factors such as whether or not he/she has a HIV test or uses condoms during sexual acts, abstain from unprotected sex. In spite of these propositions, the nexus between risk behaviour and perceived risk of HIV infection remains poorly appreciated within the circle of adolescents (Akwara, Madise, \& Hinde, 2003). Low personal HIV risk perception is very dangerous as it may fuel the spread of HIV infections among adolescents.

Some adolescents may at times feel helpless in adopting preventive measure to reduce their health risks. Even if they realized their exposures to health hazards, they sometimes deliberately chose to ignore it, thereby adopting another fatalistic attitude (Peltzer, Nzewi, \& Mohan, 2004). Nshindano and Mahara (2008) stated that failure to translate intention to avoid risky sexual behaviours into practical actions that reduce the risk of HIV infection is due to fatalistic attitude or lack of self- efficacy. The failure to adopt preventive measures in the face of apparent HIV risk is usually common in exploitative relationships and those relationships where money is the ultimate factor driving them. Another fatalistic attitude can be traced to hormonal changes in adolescence which motivates them sexually (Nshindano \& Mahara, 2008). This is primarily androgenic in origin. Adolescence is characterized by upsurge of such hormones as they begin puberty.

Adolescents represent a growing number of people living with HIV worldwide. Vaghela (2015) reported that almost $60 \%$ of all new HIV infection occurred among adolescent girls and young women in 2013. A 2016 report showed that about 610,000 adolescents between the ages of 15 - 24 were newly infected with HIV (UNICEF, 2018). According to the United Nations Children's Fund (UNICEF) (2018), number of new HIV infections among adolescents around the world is set to rise sharply unless more is done to fight the epidemic. UNICEF also stated that annual new infections in adolescents are projected to increase from 250,000 in 2015 to nearly 400,000 in 2030 which has made AIDS a leading cause of death among adolescents. UNAIDS (2017) reported that most recent data indicate that only $13 \%$ of adolescent girls and 9\% of adolescent boys aged 15-19 in Africa (the region most affected by HIV) have been tested for HIV and received the result of the last test. Additionally, AIDS-related deaths among adolescents have increased over the past decade while decreasing among all other age groups. According to Economic Section, United States Embassy in Nigeria (2011), Nigeria has the second largest number of people living with HIV/AIDS (3.1 million) and accounts for $10 \%$ of the global HIV burden with adolescents at the peak of the new infection.

The HIV/AIDS experience in Nigeria is worrisome to both researchers and educators. Reports by Daily Times (2017) show that up to 2.3 million Nigerians living with HIV/AIDS are not receiving any form of treatment. UNICEF (2018) also reported that no fewer than 170,000 adolescents were infected with HIV in Nigeria. The burden of HIV/AIDS among Nigerian adolescents is still very high (Oyo-Ita et al., 2015) and those in Enugu State appears not to be exempt. Naij (2017) reported that about 92,000 persons are living with HIV in Enugu State of Nigeria. Nwanta, Umeononigwe, Abonyi, and Onunkwo, (2011), Enugu State has a HIV/AIDS prevalence of 6.5\%, one of the highest in the country. Study carried out by Okonta, Momoh, Ekwunife, Mbagwu and Abasi (2007) in 
Nsukka metropolis showed that $28 \%$ of the secondary school adolescents believed that HIV/AIDS was real while up to $72 \%$ felt that HIV/AIDS is an illness that infects only the whites. This inaccurate belief seems to be affecting their perceptions of HIV/AIDS risk behaviours. The way secondary school adolescents perceives risk behaviours can increase their vulnerability to HIV/AIDS, as they often cannot appreciate the adverse consequence of their actions and the risks of HIV/AIDS may be particularly hard for them to grasp. To this end, the present study aims to determine secondary school adolescents' perception of risk behaviours influencing HIV/AIDS prevention and control in Nsukka Education Zone of Enugu State.

\subsection{Research Questions}

The following research questions were raised to serve as a guide to the study.

1). What is the perception of secondary school adolescents on risk behaviours associated with HIV/AIDS prevention and control?

2). What is the mean rating of male and female secondary school adolescents with respect to their perception of HIV/AIDS risk behaviours?

3). What is the mean rating of urban secondary school adolescents and rural secondary school adolescents with regard to their perception of HIV/AIDS risk behaviours?

\subsection{Hypotheses}

HO1: There is no significant difference in the mean ratings of male and female secondary school adolescents with respect to their perception of HIV/AIDS risk behaviours.

HO2: There is no significant difference in the mean ratings of rural and urban secondary school adolescents in their perception of HIV/AIDS risk behaviours.

\section{Methods and Materials}

The study used descriptive survey design. According to Ololube and Kpolovie (2012), descriptive research is used to describe characteristics of a population or phenomenon being studied. The study was conducted in Nsukka Education Zone of Enugu State, Nigeria. This education zone is made up of three Local Government Areas, namely Nsukka, Igbo Etiti and Uzo-uwani. The zone covers three LGAs out of the 17 LGAs in Enugu State. The population of the study comprised all the senior secondary school adolescents in Nsukka Education Zone of Enugu State, Nigeria. There are 58 senior secondary schools in the zone with a population of approximately 10341 secondary school adolescents. The sample for this study comprised 825 senior secondary school adolescents. The sample size calculation using Gpower 3.1 indicated that the required sample is 788 based on statistical power of 0.80 . However, in order to take care of attrition, the researchers added 37 additional secondary school adolescents completing the number to 825 secondary school adolescents, which is $7.98 \%$ of the student population. The researchers adopted multi-stage sampling technique in the course of this study. First, the researchers used simple random sampling technique to select 825 senior secondary school adolescents, and stratified random sampling technique to select 412 males and females 413 . The instrument for data collection was designed by the researchers. It was a 24-items questionnaire titled "HIV Risk Perception Questionnaire for Secondary School Adolescents". The questionnaire has two sections - A and B. Section A sought information about the respondents such as gender, class, school, age, location, income status of parents. Section B sought information on HIV risk perception among secondary school adolescents which has only one cluster and was designed on a four point Likert rating scale of Strongly Agree (SA), Agree (A), Strongly Disagree (SA), and Disagree (D) and weighed as 4, 3, 2, and 1 respectively. The face validity of the instrument was done by three experts from the Faculty of Education, University of Nigeria, Nsukka. The validators consisted of two experts from Guidance and Counselling and one expert from Measurement and Evaluation. They were requested to crosscheck the items of the instrument to ensure that they are in line with the intended purpose of the study and comprehensible. The suggestions and corrections that were given by the validators were taken into consideration in the production of the final copy of instrument. To establish the reliability of the instrument, the researchers gave 50 secondary school adolescents from three secondary schools in Oru West Education Authority the questionnaire to complete. The data collected was subjected to the test of internal consistency using Cronbach's Alpha method. The reliability coefficient of the instrument was 0.85 . The data for the study was collected through direct delivery method from 805 secondary school adolescents selected for the study. The questionnaire were administered and retrieved at the spot. In each school, the participants were briefed about the research. The researchers also guided them on the method of responding to the questionnaire.Mean and standard deviation were used to answer the research questions. Using real limit of numbers, respondent' mean score on the HRPQ ranging from 1.00-1.49 was considered as very low level of perception; scores ranging from 1.50-2.49 was considered as low level of perception; scores ranging from 
2.50-3.00 was considered as moderate level of perception; scores ranging from 3.01-3.49 was considered as high level of perception; while scores ranging from 3.50-4.00 was considered as very high level of perception. The hypotheses were tested using t-test at 0.05 probability level. The data analysis was done using Statistical Package for the Social Sciences, version 22.

\section{Results}

3.1 Research Question 1: What is the Perception of Secondary School Adolescents on Risk Behaviours Associated With HIV/AIDS Prevention and Control?

Table 1. Perception of secondary school adolescents on risk behaviours associated with HIV/AIDS prevention and control

\begin{tabular}{|c|c|c|c|c|}
\hline $\mathbf{S} / \mathbf{N}$ & HIV Risks Perception & Mean & SD & Decision \\
\hline 1 & $\begin{array}{l}\text { Avoiding sex with people who have many partners can prevent the contraction of } \\
\text { HIV/AIDS }\end{array}$ & 3.24 & 0.93 & High \\
\hline 2. & A traditional healer can give protection from HIV/AIDS & 3.24 & 0.88 & High \\
\hline 3. & Staying with one uninfected partner will help one to avoid getting HIV/AIDS & 3.09 & 1.00 & High \\
\hline 4. & There is nothing wrong with having sex with commercial sex workers & 3.14 & 0.97 & High \\
\hline 5 & HIV/AIDS can be contacted through bites from Mosquitoes and bed bugs & 3.23 & 0.93 & High \\
\hline 6 & Antibiotics can protect one from getting HIV/AIDS & 3.04 & 0.66 & High \\
\hline 7 & HIV/AIDS can be gotten through witchcraft & 2.91 & 0.97 & Moderate \\
\hline 8 & Transfusion of unscreened blood can make one contact HIV/AIDS & 3.13 & 0.79 & High \\
\hline 9 & HIV/AIDS is acquired by using the same toilet with a carrier. & 2.22 & 1.06 & Low \\
\hline 10 & There is a vaccine available to protect oneself from HIV/AIDS & 2.47 & 1.04 & Low \\
\hline 11 & Prayer can protect someone from contracting HIV/AIDS & 2.51 & 1.08 & Moderate \\
\hline 12 & HIV/AIDS is a strategy adopted to reduce people's sexual activity. & 2.74 & 1.05 & Moderate \\
\hline 13 & Abstaining from sexual intercourse can make one not to acquire HIV/AIDS & 3.23 & 1.04 & High \\
\hline 14 & HIV/ AIDS can be contacted through unprotected sexual intercourse. & 3.08 & 0.85 & High \\
\hline 15 & There is nothing wrong with having multiple sex partners. & 3.23 & 0.92 & High \\
\hline 16 & $\begin{array}{l}\text { Sharing of sharp objects (such as razors and needles) exposes one to risk of } \\
\text { HIV/AIDS. }\end{array}$ & 3.33 & 0.86 & High \\
\hline 17 & Unprotected sexual activity with a carrier can lead to HIV/AIDS. & 3.33 & 0.83 & High \\
\hline 18 & $\begin{array}{l}\text { Mouth kissing has nothing to do with sexual areas and therefore cannot lead to } \\
\text { HIV/AIDS. }\end{array}$ & 3.11 & 1.06 & High \\
\hline 19 & HIV/AIDS can be contracted through hugging & 3.04 & 0.96 & High \\
\hline 20 & Sharing eating utensils can expose one to the risk of getting HIV/AIDS & 2.94 & 0.96 & Moderate \\
\hline 21 & $\begin{array}{l}\text { Having sexual intercourse with many people with condom can secure one from having } \\
\text { HIV/AIDS. }\end{array}$ & 2.8 & 0.91 & Moderate \\
\hline 22 & HIV/AIDS can be cured with herbal medicine. & 2.7 & 0.89 & Moderate \\
\hline 23 & Engaging in oral sex can make one have HIV/AIDS & 2.63 & 1.04 & Moderate \\
\hline 24 & Engaging in anal sex can make one contract HIV/ AIDS & 2.63 & 1.04 & Moderate \\
\hline TOTAL & & 2.95 & 0.31 & Moderate \\
\hline
\end{tabular}

The result in Table 1 shows the total score $(\mathrm{M}=2.95, \mathrm{SD}=0.31)$ of the respondents which indicate that there is a moderate level of HIV/AIDS risk perception among secondary school adolescents. 
3.2 Research Question 2: What is the Mean Rating of Male and Female Secondary School Adolescents With Respect to Their Perception of HIV/AIDS Risk Behaviours?

Table 2. Mean Rating of male and female secondary school adolescents with respect to their perception of HIV/AIDS risk behaviours

\begin{tabular}{|c|c|c|c|c|c|c|c|}
\hline \multirow{2}{*}{$\mathbf{S} / \mathbf{N}$} & \multirow{2}{*}{ Items } & \multicolumn{3}{|c|}{ Males } & \multicolumn{3}{|c|}{ Females } \\
\hline & & $\mathbf{M}$ & SD & $\mathbf{D}$ & $\mathbf{M}$ & SD & $\mathbf{D}$ \\
\hline 1. & $\begin{array}{l}\text { Avoiding sex with people who have many partners can } \\
\text { prevent the contraction of HIV/AIDS }\end{array}$ & 3.42 & 0.68 & High & 3.14 & 1.02 & High \\
\hline 2. & A traditional healer can give protection from HIV/AIDS & 3.29 & 1.01 & High & 3.21 & 0.79 & High \\
\hline 3 & $\begin{array}{l}\text { Staying with one uninfected partner will help one to } \\
\text { avoid getting HIV/AIDS }\end{array}$ & 3.32 & 0.91 & High & 2.96 & 1.03 & Moderate \\
\hline 4 & $\begin{array}{l}\text { There is nothing wrong with having sex with commercial } \\
\text { sex workers }\end{array}$ & 3.04 & 0.95 & High & 3.21 & 0.98 & High \\
\hline 5 & $\begin{array}{l}\text { HIV/AIDS can be contacted through bites from } \\
\text { Mosquitoes and bed bugs }\end{array}$ & 3.11 & 0.99 & High & 3.46 & 0.88 & High \\
\hline 6 & Antibiotics can protect one from getting HIV/AIDS & 2.96 & 0.75 & Moderate & 3.09 & 0.60 & High \\
\hline 7 & HIV/AIDS can be gotten through witchcraft & 2.89 & 0.79 & Moderate & 2.93 & 1.06 & Moderate \\
\hline 8 & $\begin{array}{l}\text { Transfusion of unscreened blood can make one contact } \\
\text { HIV/AIDS }\end{array}$ & 2.97 & 0.88 & Moderate & 3.23 & 0.71 & High \\
\hline 9 & $\begin{array}{l}\text { HIV/AIDS is acquired by using the same toilet with a } \\
\text { carrier. }\end{array}$ & 2.62 & 1.09 & Moderate & 1.98 & 0.96 & Low \\
\hline 10 & $\begin{array}{l}\text { There is a vaccine available to protect oneself from } \\
\text { HIV/AIDS }\end{array}$ & 2.19 & 0.82 & Low & 2.54 & 1.15 & Moderate \\
\hline 11 & Prayer can protect someone from contracting HIV/AIDS & 2.46 & 1.10 & Low & 2.48 & 1.07 & Low \\
\hline 12 & $\begin{array}{l}\text { HIV/AIDS is a strategy adopted to reduce people's } \\
\text { sexual activity. }\end{array}$ & 2.35 & 1.02 & Low & 2.62 & 1.06 & Moderate \\
\hline 13 & $\begin{array}{l}\text { Abstaining from sexual intercourse can make one not to } \\
\text { acquire HIV/AIDS }\end{array}$ & 2.61 & 1.03 & Moderate & 2.83 & 1.04 & Moderate \\
\hline 14 & $\begin{array}{l}\text { HIV/ AIDS can be contacted through unprotected sexual } \\
\text { intercourse. }\end{array}$ & 3.29 & 0.82 & High & 3.20 & 0.88 & High \\
\hline 15 & $\begin{array}{l}\text { There is nothing wrong with having multiple sex } \\
\text { partners. }\end{array}$ & 2.89 & 0.96 & Moderate & 3.21 & 0.88 & High \\
\hline 16 & $\begin{array}{l}\text { Sharing of sharp objects (such as razors and needles) } \\
\text { exposes one to risk of HIV/AIDS. }\end{array}$ & 3.29 & 0.72 & High & 3.34 & 0.95 & High \\
\hline 17 & $\begin{array}{l}\text { Unprotected sexual activity with a carrier can lead to } \\
\text { HIV/AIDS. }\end{array}$ & 3.22 & 0.79 & High & 3.39 & 0.86 & High \\
\hline 18 & $\begin{array}{l}\text { Mouth kissing has nothing to do with sexual areas and } \\
\text { therefore cannot lead to HIV/AIDS. }\end{array}$ & 2.96 & 1.15 & Moderate & 3.21 & 1.00 & High \\
\hline 19 & HIV/AIDS can be contracted through hugging & 2.99 & 0.87 & Moderate & 3.07 & 1.01 & High \\
\hline 20 & $\begin{array}{l}\text { Sharing eating utensils can expose one to the risk of } \\
\text { getting HIV/AIDS }\end{array}$ & 3.03 & 0.84 & High & 2.89 & 1.02 & Moderate \\
\hline 21 & $\begin{array}{l}\text { Having sexual intercourse with many people with } \\
\text { condom can secure one from having HIV/AIDS. }\end{array}$ & 2.85 & 0.83 & Moderate & 2.89 & 0.96 & Moderate \\
\hline 22 & HIV/AIDS can be cured with herbal medicine. & 2.75 & 0.92 & Moderate & 2.79 & 0.88 & Moderate \\
\hline 23 & Engaging in oral sex can make one have HIV/AIDS & 2.75 & 1.08 & Moderate & 2.51 & 1.02 & High \\
\hline 24 & Engaging in anal sex can make one contract HIV/ AIDS & 3.01 & 1.02 & High & 2.78 & 1.14 & Moderate \\
\hline TOTAL & & 2.93 & 0.32 & Moderate & 2.96 & 0.29 & Moderate \\
\hline
\end{tabular}


The result in Table 2 shows the total score $(\mathrm{M}=2.93, \mathrm{SD}=0.32)$ and $(\mathrm{M}=2.96, \mathrm{SD}=0.29)$ of each group which indicate that there is a moderate level of HIV/AIDS risk perception among the male and female secondary school adolescents respectively.

\subsection{Research Question 3: What is the Mean Rating of Urban Secondary School Adolescents and Rural Secondary} School Adolescents With Regard to Their Perception of HIV/AIDS Risk Behaviours?

Table 3. Mean rating of urban secondary school adolescents and rural secondary school adolescents with regard to their perception of HIV/AIDS risk behaviours

\begin{tabular}{|c|c|c|c|c|c|c|c|}
\hline \multirow{2}{*}{$\mathrm{S} / \mathrm{N}$} & & \multicolumn{3}{|c|}{ Urban } & \multicolumn{3}{|c|}{ Rural } \\
\hline & & $\mathbf{M}$ & SD & D & M & SD & D \\
\hline 1. & $\begin{array}{l}\text { Avoiding sex with people who have many partners can } \\
\text { prevent the contraction of HIV/AIDS }\end{array}$ & 3.19 & 1.02 & High & 3.30 & 0.82 & High \\
\hline 2. & A traditional healer can give protection from HIV/AIDS & 3.39 & 0.72 & High & 3.09 & 1.01 & High \\
\hline 3. & $\begin{array}{l}\text { Staying with one uninfected partner will help one to avoid } \\
\text { getting HIV/AIDS }\end{array}$ & 3.12 & 1.09 & High & 3.08 & 0.89 & High \\
\hline 4. & $\begin{array}{l}\text { There is nothing wrong with having sex with commercial sex } \\
\text { workers }\end{array}$ & 3.17 & 0.92 & High & 3.12 & 1.02 & High \\
\hline 5. & $\begin{array}{l}\text { HIV/AIDS can be contacted through bites from Mosquitoes } \\
\text { and bed bugs }\end{array}$ & 3.64 & 0.72 & Very high & 2.99 & 1.03 & Moderate \\
\hline 6. & Antibiotics can protect one from getting HIV/AIDS & 3.08 & 0.76 & High & 3.00 & 0.54 & Moderate \\
\hline 7. & HIV/AIDS can be gotten through witchcraft & 2.97 & 0.99 & Moderate & 2.86 & 0.94 & Moderate \\
\hline 8. & $\begin{array}{l}\text { Transfusion of unscreened blood can make one contact } \\
\text { HIV/AIDS }\end{array}$ & 3.19 & 0.70 & High & 3.07 & 0.87 & High \\
\hline 9. & HIV/AIDS is acquired by using the same toilet with a carrier. & 2.05 & 0.97 & Low & 2.41 & 1.14 & Low \\
\hline 10. & $\begin{array}{l}\text { There is a vaccine available to protect oneself from } \\
\text { HIV/AIDS }\end{array}$ & 2.36 & 1.06 & Low & 2.45 & 1.04 & Low \\
\hline 11. & Prayer can protect someone from contracting HIV/AIDS & 2.46 & 1.01 & Low & 2.49 & 1.15 & Low \\
\hline 12. & $\begin{array}{l}\text { HIV/AIDS is a strategy adopted to reduce people's sexual } \\
\text { activity. }\end{array}$ & 2.58 & 1.14 & Moderate & 2.46 & 0.95 & Low \\
\hline 13. & $\begin{array}{l}\text { Abstaining from sexual intercourse can make one not to } \\
\text { acquire HIV/AIDS. }\end{array}$ & 2.82 & 1.05 & Moderate & 2.67 & 1.03 & Moderate \\
\hline 14. & $\begin{array}{l}\text { HIV/ AIDS can be contacted through unprotected sexual } \\
\text { intercourse. }\end{array}$ & 3.28 & 0.87 & High & 3.19 & 0.84 & High \\
\hline 15. & There is nothing wrong with having multiple sex partners. & 3.14 & 0.92 & High & 3.04 & 0.92 & High \\
\hline 16. & $\begin{array}{l}\text { Sharing of sharp objects (such as razors and needles) exposes } \\
\text { one to risk of HIV/AIDS. }\end{array}$ & 3.21 & 0.99 & High & 3.44 & 0.69 & High \\
\hline 17. & $\begin{array}{l}\text { Unprotected sexual activity with a carrier can lead to } \\
\text { HIV/AIDS. }\end{array}$ & 3.33 & 0.85 & High & 3.33 & 0.82 & High \\
\hline 18. & $\begin{array}{l}\text { Mouth kissing has nothing to do with sexual areas and } \\
\text { therefore cannot lead to HIV/AIDS. }\end{array}$ & 3.21 & 1.04 & High & 3.01 & 1.09 & High \\
\hline 19. & HIV/AIDS can be contracted through hugging & 3.11 & 0.92 & High & 2.97 & 0.99 & Moderate \\
\hline 20. & $\begin{array}{l}\text { Sharing eating utensils can expose one to the risk of getting } \\
\text { HIV/AIDS }\end{array}$ & 2.92 & 1.07 & Moderate & 2.96 & 0.83 & Moderate \\
\hline 21. & $\begin{array}{l}\text { Having sexual intercourse with many people with condom } \\
\text { can secure one from having HIV/AIDS. }\end{array}$ & 2.93 & 0.88 & Moderate & 2.84 & 0.95 & Moderate \\
\hline 22. & HIV/AIDS can be cured with herbal medicine. & 2.97 & 0.84 & Moderate & 2.56 & 0.91 & Moderate \\
\hline 23. & Engaging in oral sex can make one have HIV/AIDS & 2.78 & 0.95 & Moderate & 2.47 & 1.12 & Low \\
\hline 24. & Engaging in anal sex can make one contract HIV/ AIDS & 2.67 & 1.13 & Moderate & 3.07 & 1.02 & High \\
\hline \multicolumn{2}{|c|}{ TOTAL } & 2.98 & 0.29 & Moderate & 2.91 & 0.31 & Moderate \\
\hline
\end{tabular}


The result in Table 3 shows overall score $(\mathrm{M}=2.98, \mathrm{SD}=0.29)$ and $(\mathrm{M}=2.91, \mathrm{SD}=0.31)$ of each group which indicate that there is a moderate level of HIV/AIDS risk perception among the urban and rural secondary school adolescents respectively.

3.4 HO1: There Is no Significant Difference in the Mean Ratings of Male and Female Secondary School Adolescents With Respect to Their Perception of HIV/AIDS Risk Behaviours

Table 4. T-test analysis of male and female secondary school adolescents' mean ratings on HIV/AIDS risk behaviours

\begin{tabular}{llllllll}
\hline Gender & $\mathbf{N}$ & Mean & SD & T & Df & Sig(2- tailed) & $\mathbf{9 5 \% ~ C I ~}$ \\
\hline Male & 317 & 2.93 & 0.32 & -1.34 & 823 & .180 & $-.07244, .01363$ \\
Female & 508 & 2.96 & 0.29 & & & & \\
\hline
\end{tabular}

$\mathrm{N}=$ number of respondents; $\mathrm{SD}=$ Standard deviation; $\mathrm{df}=$ degree of freedom; $\mathrm{CI}=$ confidence interval.

The result of hypothesis testing in Table 4 shows that the $\mathrm{p}$-value reported $(\mathrm{p}=.180)$ is greater than .05 level of significance. This means that there is no significant difference in the mean ratings of male and female secondary school adolescents with respect to their perception of HIV/AIDS risk behaviours, $t(823)=-1.34, p=.180$. Thus, the null hypothesis is not rejected.

3.5 HO2: There Is no Significant Difference in the Mean Ratings of Rural and Urban Secondary School Adolescents in Their Perception of HIV/AIDS Risk Behaviours.

Table 5. T-test analysis of rural and urban secondary school adolescents' mean ratings on HIV/AIDS risk behaviours

\begin{tabular}{llllllll}
\hline Location & N & Mean & SD & T & df & Sig(2-tailed) & 95\% CI \\
\hline Urban & 426 & 2.98 & 0.29 & 3.353 & 823 & .001 & $.02949, .11279$ \\
Rural & 399 & 2.91 & 0.32 & & & & \\
\hline
\end{tabular}

$\mathrm{N}=$ number of respondents; $\mathrm{SD}=$ Standard deviation; $\mathrm{df}=$ degree of freedom; $\mathrm{CI}=$ confidence interval.

The result of hypothesis testing in Table 5 shows that the $p$-value reported $(p=.001)$ is less than .05 level of significance. This means that there is significant difference in the mean ratings of urban and rural secondary school adolescents with respect to their perception of HIV/AIDS risk behaviours, $t(823)=3.352, p=.001$. The difference observed is in favour of urban secondary school adolescents. Thus the null hypothesis is rejected.

\section{Discussion}

The study found out that the perception of secondary school adolescents associated with HIV/AIDS prevention and control is moderate. This finding contradicts that of Adogu, Udigwe, Nwabueze, Adinma, Udigwe, and Onwasigwe (2015) who discovered that risk perception among secondary school adolescents is high. Also, the finding contradict that of Darteh, Kumi-Kyereme, and Awusabo-Asare (2016) who discovered that adolescents' perception of risk of HIV was generally low. It also contradicts that of Kibombo, Neema, and Ahmed (2007) who discovered that the risk perception of HIV/AIDS among the secondary school adolescents was low.

Another finding of this study is that the mean rating of male and female secondary school adolescents with respect to their perception on HIV/AIDS risk behavior is moderate. The study also found out that there is no significant difference in the mean ratings of male and female secondary school adolescents with respect to their perception of HIV/AIDS risk behaviours. The findings contradicts that of Kibombo, Neema, and Ahmed (2007) who discovered that significant gender differences exist in terms of perception of HIV/AIDS in favor of the males. Also Bhasin (1996) revealed that there was a significant difference between male and female on perception of risk of HIV infection. More female than male showed a positive perception of HIV/AIDS risk behaviours. The findings contradicts those of Steinberg and Monahan (2007) who found out that gender factor is very influential in determining the level of risk behavior of individuals as female were found much likely to perceive risk than male.

This study further found that the mean rating of urban secondary school adolescents and rural secondary school adolescents with regard to their perception of HIV/AIDS risk behaviours is moderate. The study further found that there is significant difference in the mean ratings of urban and rural secondary school adolescents with respect to their perception of HIV/AIDS risk behaviours in favour of urban secondary school adolescents. This finding contradicts that of Danjin and Onajole (2009) who discovered that there was no significant difference found in 
level of awareness about HIV/AIDS between urban and rural respondents. The finding supports that of Vaghela (2015) who revealed that adolescents of urban area have high perception regarding the HIV/AIDS risk behaviours compared to their rural counterparts.

The secondary school adolescents should be given proper and adequate guidance on HIV/AIDS risk behaviours. Parents should be exposed to proper and best practices of keeping safe from HIV/AIDS risk behaviours. Professional counselors need to be employed and retrained on training programmes, capacity-building workshops and refresher courses on HIV/AIDS education and prevention approaches. School rules and regulations regarding exposure to HIV/AIDS risk behaviours should be strengthened. School AIDS education programme in Enugu State and other eastern states in Nigeria should be reinforced with well-designed televised messages targeted at sensitizing secondary school students in the States about the potential risks of HIV infection at their age. Voluntary Counseling and Testing (VCT) services should be reinforced in all secondary schools in Enugu State. Similar risk behavioural surveys should be carried out among out-of-school adolescents in Enugu state.

Further studies could be carried out using a larger population to substantiate the urgency for counseling programme to meet the secondary school adolescents' needs on HIV/AIDS risk behaviours. Further research could also be focused on factors that affect adolescents' perception of risks which makes them vulnerable to HIV/AIDS. Further studies could also be carried out to examine the effects of HIV/AIDS moderate risk perception on secondary school adolescents. Studies could also be conducted among out-of-school adolescents to find out their own level of HIV/AIDS risk perception.

\section{Conclusion}

The study concludes that there is a moderate level of HIV/AIDS risk perception among secondary school adolescents in the study area. The level of HIV/AIDS risk perception among the male and female secondary school adolescents is moderate. There is a moderate level of HIV/AIDS risk perception among the urban and rural secondary school adolescents. There is no significant difference in the mean ratings of male and female in-school adolescents with respect to their perception of HIV/AIDS risk behaviours. Finally, there is significant difference in the mean ratings of urban and rural in-school adolescents with respect to their perception of HIV/AIDS risk behaviours in favour of urban secondary school adolescents. Further studies could be carried out using a larger population to substantiate the urgency for counseling programme to meet the secondary school adolescents' needs on HIV/AIDS risk behaviours. Further research could also be focused on factors that affect adolescents' perception of risks which makes them vulnerable to HIV/AIDS.

\section{Competing Interests Statement}

The authors declare that there are no competing or potential conflicts of interest.

\section{References}

Adeyi, O., Kanki, P. J., Odutolu, O., \& Idoko, J. A. (2006).AIDS in Nigeria: A Nation on the Threshold. Cambridge, MA: Harvard Centre for Population and Development Studies.

Adogu, P., Udigwe, I., Nwabueze, A., Adinma, E., Udigwe, G., \& Onwasigwe, C. (2015). Sexual health knowledge, attitude and risk perception among in-school and out-of-school female adolescents in Onitsha, Anambra State, Nigeria. South Eastern European Journal of Public Health, 2(1).

Akwara P. A., Madise, N. J., \& Hinde, A. (2003). Perception of Risk of HIV/AIDS And Sexual Behaviour In Kenya. Journal of Biosocial Science, 35(3), 385-411. https://doi.org/10.1017/S0021932003003857

Avert. (2017). History of HIV and AIDS Overview. Retrieved from https://www.avert.org/professionals/history-hiv-aids/overview

Bhasin, S., Storer, T. W., Berman, N., Callegari, C., Clevenger, B., Phillips, J., ... \& Casaburi, R. (1996). The effects of supraphysiologic doses of testosterone on muscle size and strength in normal men. New England Journal of Medicine, 335(1), 1-7. https://doi.org/10.1056/NEJM199607043350101

Centers for Disease Control and Prevention. (December 4, 2015). HIV Risk Behaviors. Retrieved from https://www.cdc.gov/hiv/risk/estimates/riskbehaviors.html

Daily Times. (February 8, 2017). Enugu: HIV cases decreasing. Retrieved from: https://dailytimes.ng/health/enugu-hiv-cases-decreasing/

Danjin, M., \& Onajole, A. (2009). HIV/AIDS Risk Behavioural Tendencies Among Secondary School Students in Gombe (Nigeria).The Internet Journal of Health, 11(1).

Darteh, E. K., Kumi-Kyereme, A., \& Awusabo-Asare, K. (2016). Perception of Risk of HIV among Adolescents' Living in an Urban Slum in Ghana. African Journal of Reproductive Health, 20(1), 62-70. 
https://doi.org/10.29063/ajrh2016/v20i1.6

Economic Section, United States Embassy in Nigeria. (December 2011). Nigeria HIV Fact Sheet. Retrieved from http://photos.state.gov/libraries/nigeria/231771/Public/DecemberHIVFactSheet.pdf

FMOH. (2005). National HIV seroprevalence sentinel survey. Republic of Nigeria, FMOH Expert Committee Report Series. Retrieved from http://www.nigeria-aids.org/pdf/2005SentinelSurvey.pdf

Gupta, R. (2000). Gender, Sexuality, and HIV/AIDS: the what, the why, and the how. Plenary Address for the 13th International AIDS Conference, Durban, South Africa.

Kibombo, R., Neema, S., \& Ahmed, F. H. (2007). Perceptions of risk to HIV infection among adolescents in Uganda: are they related to sexual behaviour?.African Journal of Reproductive Health, 11(3), 168.https://doi.org/10.2307/25549738

Naij. (2017). 92,000 Live With HIV in Enugu. Retrieved from https://www.naij.com/8147.html.

Nashindano, C., \& Maharaj, P. (2008). Reasons for Multiple Sexual Partnerships: Perspectives of Young People in Zambia. African Journal of AIDS Research, 7(1), 37-44.https://doi.org/10.2989/AJAR.2008.7.1.5.433

Nwanta, J. A., Umeononigwe, C. N., Abonyi, G. E., \& Onunkwo, J. I. (2011). Retrospective study of bovine and human tuberculosis in abattoirs and hospitals in Enugu State, Southeast Nigeria. Journal of Public Health and Epidemiology, 3(7), 329-336.

Okonta, J. A., Momoh, M. A., Ekwunife, O. I., Mbagwu, I. S., \& Abali, S. O. (2007). Assessment of HIV/AIDS awareness and changes in sexual practices among secondary school students in Nsukka environment. Tropical Doctor, 37(4), 269-271. https://doi.org/10.1258/004947507782333071

Ololube, N. P., \& Kpolovie, P. J. (2012). Approaches to conducting scientific research in education, arts and the social sciences. Online Journal of Education Research, 1(3), 44-56.

Oyo-Ita, A. E., Ikpeme, B. M., Etokidem, A. J., Offor, J. B., Okokon, E. O., \& Etuk, S. J. (2005). Knowledge of HIV/AIDS among secondary school adolescents in Calabar-Nigeria.

Peltzer, K., Nzewi, E., \& Mohan, K. (2004).Attitudes towards HIV-antibody testing and people with AIDS among university students in India, South Africa and United States. Indian Journal of Medical Sciences, 58, 95-108

Remedy Health Media. (2017). History of HIV/AIDS. Retrieved from http://www.healthcommunities.com/hiv-aids/history.shtml

Richmond, T. (2014). Risky Behaviour Training Programme. Retrieved from http://www.richmond.gov.uk/risky_behaviour_programme

Smriti N., \& Marfatia, Y. S. (2010). Adolescent HIV/AIDS: (Issues and challenges). Indian Journal of Sexually Transmitted Diseases, 31(1), 1-29. https://doi.org/10.4103/0253-7184.68993

Ssengonzi, R., Schlegel, A., Anyamele, C., \& Olson, K. (2004).Assessing educators views on the impact of HIV/AIDS on primary education in Nigeria. Study Report. US Agency for International Development, RTI International, Research Triangle Park, NC.

Steinberg, L., \& Monahan, K. C. (2007).Age differences in resistance to peer influence. Developmental Psychology, 43(6), 1531. https://doi.org/10.1037/0012-1649.43.6.1531

UNAIDS. (2017). HIV/AIDS Rstimates. Retrieved from http://www.unaids.org/en/regionscountries/countries/nigeria

UNICEF. (2018). Every three minutes a teenage girl is infected by HIV. Retrieved from https://www.unicef.org/wca/press-releases/every-three-minutes-teenage-girl-infected-hiv-unicef

Vaghela, K. J. (2015). A Study of Awareness of HIV/AIDS among Adolescents: (Girls and Boys of Urban and Rural Area). The International Journal of Indian Psychology, 3, 886.

Zwar, N. A., Mendelsohn, C. P., \& Richmond, R. L. (2014). Supporting smoking cessation. BMJ, 348, f7535. https://doi.org/10.1136/bmj.f7535

\section{Copyrights}

Copyright for this article is retained by the author(s), with first publication rights granted to the journal.

This is an open-access article distributed under the terms and conditions of the Creative Commons Attribution license (http://creativecommons.org/licenses/by/4.0/). 